\title{
Primary care nurses' approach to cases of violence against children ${ }^{1}$
}

\author{
Ailton de Souza Aragão² \\ Maria das Graças Carvalho Ferriani ${ }^{3}$ \\ Telma Sanchez Vendruscollo ${ }^{4}$ \\ Sinara de Lima Souza ${ }^{5}$ \\ Romeu Gomes ${ }^{6}$
}

In Primary Care, the field of nursing comes face-to-face with the complexity of violence, leading these professionals to constantly re-evaluate their habitus. Objective: to analyze how cases of violence against children and adolescents are approached by primary care nurses, identifying limits and possibilities for dealing with these cases. Method: a qualitative study, undertaken in 2011, through semi-structured interviews with 8 out of 48 nurses in the Family Health teams in the city of Uberaba in the state of Minas Gerais, the analysis of which followed the interpretation of meanings, based in dialectical hermeneutics. Results: the following stand out: non-identification of violence as a problem for the nurses; denunciations and notifications as a role of the nurses; and the limits found in the face of violence. Conclusion: it is determined that the habitus of nursing directed at health promotion and prevention of violence must be restructured, overcoming the biomedical paradigm and involving intersectorial and multidisciplinary actions.

Descriptors: Public Health Nursing; Nursing Primary Care; Defense of Children and Adolescents; Comprehensive Health Care; Violence.

\footnotetext{
1 This research was supported by Fundação de Amparo à Pesquisa do Estado de São Paulo (FAPESP), process \# 2010/51707-9.

2 PhD, Professor, Universidade Federal do Triângulo Mineiro, Brazil.

${ }^{3}$ PhD, Full Professor, Escola de Enfermagem de Ribeirão Preto, Universidade de São Paulo, WHO Collaborating Centre for Nursing Research Development, Brazil.

${ }^{4}$ PhD, Professor, Departamento de Ciencias Humanas e Sociais, Universidade de Ribeirão Preto, Brazil.

${ }^{5} \mathrm{PhD}$, Adjunct Professor, Departamento de Saúde, Universidade Estadual de Feira de Santana, Brazil.

${ }^{6}$ PhD, Full Professor, Instituto Fernandes Figueira e Escola de Saúde Pública, Fundação Oswaldo Cruz (FIOCRUZ), Brazil.
}

Corresponding Author: Ailton de Souza Aragão Universidade Federal do Triângulo Mineiro. Departamento de Medicina Social Av. Getúlio Guaritá, 159 Bairro Abadia CEP: 38025-440, Uberaba, MG, Brasil

E-mail: as_aragao@hotmail.com 


\title{
Abordagem dos casos de violência à criança pela enfermagem na atenção básica
}

$\mathrm{Na}$ atenção básica, o campo da enfermagem se depara com a complexidade da violência, levando esses profissionais a reavaliarem constantemente seu habitus. Objetivo: analisar como os casos de violência contra crianças e adolescentes são abordados pela enfermagem, na atenção básica, identificando limites e possibilidades para se lidar com esses casos. Método: estudo qualitativo, realizado em 2011, com entrevistas semiestruturadas com 8 dos 48 enfermeiros das Equipes de Saúde da Família, da cidade de Uberaba, MG, e cuja análise seguiu a interpretação dos sentidos, baseada na hermenêutica dialética. Resultados: destacam-se a não identificação da violência como problema do enfermeiro, as denúncias e notificações como função do enfermeiro e os limites encontrados ante as situações de violência. Conclusão: constata-se que o habitus de enfermagem, voltado para a promoção à saúde e à prevenção das violências deve ser reestruturado, superando o paradigma biomédico e envolvendo ações intersetoriais e multiprofissionais.

Descritores: Enfermagem em Saúde Pública; Enfermagem de Atenção Primária; Defesa da Criança e do Adolescente; Assistência Integral à Saúde; Violência.

\section{Aproximación de la violencia a los niños por enfermeras en la atención primaria}

\begin{abstract}
En la atención primaria, la enfermería se enfrenta a la complejidad de la violencia, teniendo estos profesionales que reevaluar constantemente su habitus. Objetivo: analizar cómo los casos de violencia contra niños, niñas y adolescentes son tratados por enfermeras en la atención primaria, la identificación de los límites y las posibilidades de hacer frente a estos casos. Método: estudio cualitativo, realizado en el 2011, con entrevistas semi-estructuradas con 08 de las 48 enfermeras de los Equipos de Salud Familiar de Uberaba-MG y cuyo análisis siguió la interpretación de significados, basado en la hermenéutica dialéctica. Resultados: destaca el hecho de no identificar el problema de la violencia como una enfermera, quejas y notificaciones en función de la enfermera y de los límites que se encuentran en la cara de la violencia. Conclusión: el hábito de la enfermería se centró en la promoción de la salud y la prevención de la violencia debe ser reestructurada, superando el paradigma biomédico y la participación de la acción multidisciplinaria e intersectorial.
\end{abstract}

Descriptores: Enfermería en Salud Pública; Atención Primaria de Enfermería; Defensa de la Niñez y la Adolescencia; Atención Integral de Salud; Violencia.

\section{Introduction}

Nursing is a field - a term understood here as meaning a structured space where agents and institutions are inserted and which has its own history and relative autonomy(1-2) - which historically has been constituted as complementary to medicine(3).

In Brazil, the institutionalization of nursing started in the 1920's, through a partnership established between the National Department of Public Health (DNSP) and the Rockefeller Foundation of the United States of America. Initially, this field was limited to care in infancy, to the prevention of tuberculosis and sexually-transmitted diseases, and to carrying out prenatal checkups(3). Over a period of more than nine decades, the profession has widened its scope of activities.
During this period, habitus - understood here as long-lasting dispositions which create and organize the practices ${ }^{(4)}$ - was preserved and altered within the profession. In other words, a cultural capital was being structured for the production of specific practices in nursing, which conferred upon it a professional identity. In the ambit of primary care, the profession has been reorienting its actions such that it may cover the service users' health needs, and not be limited to medicalcurative rationality(5).

This cultural possession of the profession confronted and continues to confront challenges which can result in its transformation, creating new practices. This occurs principally when situations require perspectives 
which do not run out in the biomedical habitus. The confrontation of violence is one of the problems which demands restructuring of the structured and structuring capacities of health professionals in general and nurses in particular.

For the World Health Organization, violence is seen as "the use of physical force or power, threatened or actual, against oneself, against another person, or against a group or a community, that results in or has a high likelihood of resulting in injury, death, psychological harm, maldevelopment, or deprivation."(6). Based in this definition and in the observation of violence's impact on the life of communities, violence is a complex problem, not only for the area of health, but also for other sectors of society.

Children and adolescents, according to epidemiological data, are among the populational segments which are most vulnerable to suffering through the violation of their rights, their physical, mental and emotional health being directly and indirectly affected(7). In the face of the relevancy of such occurrences, it is to be hoped that health professionals might develop a sharp sense for them, as well as competencies and skills for dealing with these cases.

Specifically in relation to nursing, the scientific literature has indicated some possibilities and limits related to confronting violence committed against children and adolescents on the part of professionals from this field. Prevention as a way of confronting this problem - in its three levels - has been emphasized recurrently as one of the principal focuses of nursing ${ }^{(8-10)}$.

Several research projects $^{(8-11)}$ have observed that it falls to nursing professionals in Primary Care - along with the health team - to participate in the confronting of violence against children and adolescents. Among the actions suggested by the researchers, although already presented by the $\mathrm{WHO}$, the following stand out: to act in strategies aimed at reducing the incidence and prevalence of cases of violence (primary prevention); to identify the potential risk of violence in families in the community and during specific acts of care, such as the pre-natal check-up and during pediatric consultations (secondary prevention) and to promote support for the resolution of the problem once detected (tertiary prevention).

In relation to the limits on nursing's activities in the face of violence against children and adolescents, lack of preparedness - whether in the theoretical plane or in the scope of practice - has been observed recurrently in various studies ${ }^{(8-12)}$. These same studies suggest the existence of groups, and the supervision of the nursing actions, to overcome the limits of the nurses' training and professional experience ${ }^{(8-12)}$.

These preliminary reflections indicate nursing's need to widen and deepen the investigation of the addressing of violence against children and adolescents in primary care; as the issue's complexity is best understood in the dialectical relationship between the consolidated knowledge and practice of its professionals.

Based on this perspective, this study aims to analyze how the cases of violence against children and adolescents are approached in primary care nursing, identifying the limits and possibilities for dealing with these cases.

\section{Methodological Design}

This research is part of a project of studies whose central objective is to investigate and analyze the activities of the social protection network for children and adolescents in the municipality of Uberaba in the Brazilian state of Minas Gerais, from the perspective of the social subjects involved. The present investigation, undertaken in 2011 in the municipality of Uberaba, Minas Gerais, was approved by the Research Ethics Committee of the Ribeirão Preto College of Nursing/University of São Paulo, protocol number 1286/2011. In the present work, the authors focus on questions related to nursing's role - within the ambit of primary care - in the face of violence perpetrated against children and adolescents.

The investigation is grounded in principles of qualitative research, here understood as a set of interpretive practices which seek to investigate the meanings which the subjects attribute to the phenomena and to the set of relationships into which they insert themselves. Among other aspects, this approach seeks to understand the reality experienced by the social subjects in their historical-dialectical magnitude ${ }^{(13-14)}$.

At the time of the field work, the municipality being studied was divided into three health districts. Health districts I and II were selected in the research because they were considered more socially vulnerable, based on the studies of the Program for Integrated Actions and References in Confrontation of Sexual Violence Against Children and Adolescents in Minas Gerais (PAIR), 2006/2007(15).

This study's subjects are nurses, included in the research because they work in Primary Care in the urban area, for more than one year, in those areas recognized 
as having a high level of social vulnerability. Based on these inclusion criteria, 08 of the 48 nurses working in Primary Care were interviewed, of whom 7 were from Health District I and 01 from Health District II.

The collection of information was based in semistructured interviews, with the following guiding questions: What is the procedure like that you follow in the face of cases of violence against children and adolescents? What are the difficulties that you have in relation to this question? These questions were about the process of detection, reception and referral of situations of violence by the professional, and his or her understanding of the phenomenon.

Regarding data analysis, the researchers used the method of interpretation of meanings, based on hermeneutical-dialectical principles for the interpretation of the statements' contexts, reasons and logics(16). The analytical-interpretive trajectory followed the following phases: (a) a thorough reading of the statements; (b) identification of the feelings attributed to the ways of dealing with violence committed against children and adolescents; (c) elaboration of analytical axes, carried out based on the breaking down of what was described in structuring elements of the accounts and taking into account the symbolic aspects present in these accounts; (d) interpretation, in which the authors elaborate a summary of what was analyzed, produced in the dialog between empirical material and the study's theoretical perspective.

\section{Results}

Of the 8 interviewees, one was male and seven female, with varying ages and an average age of 36 years. On average they had worked as health professionals for four years and nine months; the smallest time was one year and three months, and the longest, twelve years. All had studied nursing at university and had attended the following specialization courses: Working in Emergency ICU, Education, Family Health, Public Health, Administration in Health Services, Hospital Hotel Services, Occupational Nursing and Obstetrics.

The meanings subjacent to the health professionals' accounts reveal three analytical axes: failure to identify the violence as the nurse's problem; denunciations and notification as the nurse's role and limits met regarding situations of violence.

Failure to identify the violence as the nurse's problem

In general, violence against children and adolescents is not recognized as a problem to be resolved by nursing The interviewees repeatedly associate the problem as the responsibility of other professionals in the team or outside it. Like, when a case like this (...) happens [of violence], we usually pass it over to the social worker [based in the same Health Center] (subject 3). And further: we do what we can, we forward it, where possible, to the psychologist. Truth to tell, we haven't done prevention [against violence]. In relation to this subject, primary care really leaves a lot to be desired. We could have done better (Subject 4).

The statements seem to move in an opposite direction from the discussion promoted in the literature on the subject, which, in the face of this problem, recognizes that nursing actions within the scope of primary care are also appropriate(8-9).

Among the statements, there is no mention of discussing cases with the other members of the Health Team; there is no mention of even one action shared with other public or private persons, or even other sectors, such as education or special social protection.

On the other hand, based in the meanings subjacent to the statements, it may be observed that the feeling of impotence in the face of the detection of violence impels the nurse to transfer the problem to others, whether this be the Family Health Strategy doctor or some other professional, such as the psychologist or the social worker.

\section{Denunciations, notification, or passing the 'case' on, as the role of the nurse}

The accounts show that the subjects' actions are restricted to notifications and/or referring cases to the doctors, to the members of the Family Health Support Centers (NASF), such as the psychologist and social worker, to the Reference centers for Social Assistance (CRAS) and to the Council of Guardianship. Denunciation is also mentioned. I go straight to the person who can sort it out, the public prosecutor, who's my friend, and I make the denunciation to him (subject 5). But others are actioned: The social worker [from the NASF], with support from the CRAS and other places, facilitates this [the referral] for us, because it's already in this environment and we forward the problems we have to her (subject 7).

In notifying, referring or denouncing, the present study's interviewees are acting in accordance with the Nursing Code of Ethics which prohibits them from "provoking, cooperating, colluding or failing to act in any form of violence", a precept from Resolution 311/2007 of the Federal Council of Nursing (COFEN), section IArt. 34. 
They are also acting in accordance with the Statute of the Child and Adolescent (ECA) which includes them in the set of professionals who must notify the authorities when they suspect or identify cases of violence.

Notification is one of the assignments of health care professionals in general, and nurses in particular(17). This procedure turns into an epidemiological indicator of violence $^{(11)}$ which provides a means for the redirection of action in a given population's territory* and/or the construction of public policies ${ }^{(18)}$. However, this action requires a control of the flows of notification of the facts of violence such that referrals may be made to the defense network or to the social care network ${ }^{(19-20)}$.

Problems related to ignorance or discontinuity of flows result in some interviewees acting in a manner which is isolated, disarticulated or reliant on personal contacts. Counter-referral doesn't come from there to here (...) it's not all structured in the network (subject 4). And in the health sector The counter-referrals never come from the Teaching Hospital, from the hospitals [of the city] and not from the professionals in the network themselves (subject 6).

In some reports, it may be observed that the act of notifying, in a certain form, leads to the health professionals not carrying out acts to prevent new facts or even to intervene in the social causes of violence.

The denunciation of the problem may also be understood as something which can compromise the relationships established between the health professionals and the community, as it generates fear. It's better to take it slowly, so we don't lose the link with them (...). If we denounce somebody, they are repressive and it's our work that is compromised. (subject 1 ).

Non-denunciation of the problem can be understood as a protection strategy in the face of aggressors, to the degree that it maintains the links with the community, but can also hide chronic situations of violence, leading to under-reporting ${ }^{(21)}$.

In summary, passing a case on to other subjects, even though institutionally disarticulated ${ }^{(21)}$ can denote that the nurses are insecure about their responsibilities in the face of the complexity of violence against children and adolescents, although these are expressed in the guidance from COFEN and ECA ${ }^{(22)}$.

\section{Limits found in the face of situations of violence}

The meanings which the nurses attribute to dealing with violence against children and adolescents show certain limits, the principal one of which is to do with gaps in these professionals' training, as they feel unprepared to exercise actions in the face of the problem in question. These gaps may be seen even in relation to notification. Well, with a child [victim of violence] we've never had that here, but if it did happen, we'd have to ask the social worker to tell us what to do (subject 3). And further: You have to know who you're referring to, and why, [and which] paths you'll take to resolve the problem. We have a certain difficulty in relation to health (subject 6 ).

One can observe from the collection of statements that nursing training leads to the primary care nurse's activities remaining centered in the concept of health as the absence of diseases. In this regard, the professional's attention is removed from the problem and centered on illnesses. What happens most here is hypertension, diabetes, things related to women's health, nothing else (...) Respiratory problems, bronchitis (...) don't just attack children, but the elderly too (subject 2).

It is not just the interviewees who feel unprepared for dealing with violence against children and adolescents. Various studies have brought up this unpreparedness ${ }^{(8-12)}$.

The unpreparedness, however, does not totally dull the sensitivity which some interviewees express concerning situations which may potentialize the existence of violence against children and adolescents. You see ten-year-old girls playing unsupervised on the street. And sometimes the parents have to work, and they can't always find a crèche where their children are more protected. They end up hanging around in the street and a lot of violence happens. The ways that parents bring up their children around here are also very aggressive (...). The youngsters and the women don't have jobs and they just hang around (...). here in front of the health center there's a bunch of drug addicts (subject 1). There are, however, other social problems: This is a dangerous neighborhood, surrounded by violence and the very poor. We have cases of people on low incomes, with little education (subject 7).

The awareness, sometimes, can also lead to an understanding that violence can produce unexpected reactions and responses, ranging from fear to direct confrontation. [You have to be careful ] with them [the aggressors] so they don't take vengeance on us (subject 1). I have clashed with the drug-dealers lots of times over problems with the children. (...). On visiting one family, I found myself in a house full of people using drugs (subject 5).

At the same time, the fears of confronting the

*'Territory' here is meant in the sense of the population in question's various dimensions of social interactions, cultural expressions, labor relations and history of urban occupation, among others, a concept developed by the Brazilian geographer Milton Santos. Translator's note. 
problem, in the statements, also show that the feeling of impotence in the face of the detection of violence impels the nurse to transfer the problem to another person, such as the Family Health Strategy physician or to other professionals, including the psychologist and social worker.

The limits revealed in the empirical evidence and brought up in the literature on this issue impose epistemological challenges on nursing, to ensure that the understanding of violence should neither be fragmentary nor isolate individuals from their historical context of vulnerabilities. Overcoming this challenge can contribute to an integral approach both for the subjects and for the phenomenon and the conditions which it creates $^{(14,23-25)}$.

\section{Interpretive summary}

One of the explanations for nursing's failure to identify the problem of violence against children and adolescents is to do with the fact of the nurse's professional habitus being strongly based in the biomedical model, with anatomo-physio-pathological components which structure their way of acting. In this regard, some of the professionals in this field cannot deal with situations which are not intelligible through the biomedical model alone - as is the case with violence discussed here.

In this list of attendances given by the nurses, the biologist bias has apparently prevailed, as the nurses concentrate their interventions in the health problems to the detriment of reflecting on the causes of the violence or on preventive actions.

This failure in identification means that, on the one hand, the nurses do not carry out actions for the prevention of violence, and that on the other there is a transference of the problem to the fields of other disciplines, seen by the nurses as more competent to seek solutions. One of the aspects underlying these situations is the fact that nurses feel unprepared to act.

The practice of passing on the cases of violence to other professionals or sectors of the System of Assurance of Rights shows that the nurses in Primary Care run into innumerable challenges. One of these is the nurses' failure to see themselves as subjects in the process of confronting a complex and multicausal phenomenon such as violence.

For this to be overcome, it is necessary for professional skills to be restructured so as to seek other semiologies and semiotechniques. In this regard, new epistemological references must be used, such that the problem of violence affecting children and adolescents may be seen not only in terms of etiological and nosological frameworks.

\section{Final Considerations}

The empirical material reveals that the nonidentification of violence as the nurse's problem may both be related to the lack of programmed guidance on the subject in daily nursing practice, and indicate the need for the professional category to invest more in defining roles so as to participate in the resolution of this grave public health problem.

It is known that due to the complexity of the problem, it cannot be situated in an isolated way as a role of nursing alone, or of any other category of health professional. Understanding, however, that this complexity entails a multidisciplinary perspective and intersectorial actions, nursing can act as part of collective actions.

Following this logic, and understanding that in the scope of the Family Health Strategy information can be produced and cross-checked with that from other sectors concerning the problem focused on here, nursing can progress beyond episodic and individualized attendance and participate in social networks in reflecting about vulnerable conditions of living and the guaranteeing of rights, as well as constituting potential nursing actions for confronting violence against children and adolescents.

\section{References}

1. Bourdieu P. Os usos sociais das ciências: por uma sociologia clínica do campo científico. São Paulo: UNESP; 2003. 86 p.

2. Bonnewitz P. Primeiras lições sobre a sociologia de P. Bourdieu. Petrópolis: Vozes; 2003. 152 p.

3. Moreira MCN. A Fundação Rockefeller e a construção da identidade profissional de enfermagem no Brasil na Primeira República. História Ciência Saude-Manguinhos, fev 1999; 5(3):621-45.

4. Bourdieu P. Esboço de uma teoria da prática. Oiras, Portugal: Celta Editora; 2002. 276 p.

5. Matumoto S, Fortuna CM, Kawata LS, Mishima 
SM, Pereira MJB. Nurses' Clinical practice primary care: a process under construction. Rev. Latino-Am. Enfermagem jan-fev 2011;19(1):123-30.

6. Organização Mundial da Saúde (OMS). Relatório mundial sobre violência e saúde. Brasília: OMS/OPAS; 2002.

7. Souza ER, Mello Jorge MHP. Impacto da violência na infância e adolescência brasileiras: magnitude da morbimortalidade. In: Ministério da Saúde (BR). Violência faz mal à saúde. Brasília: Ministério da Saúde; 2006. 298 p. (Série B. Textos Básicos de Saúde).

8. Algeri S, Souza LM. Violence against children and adolescents: a challenge in everyday nursing staff. Rev. Latino-Am. Enfermagem. 2006;14(4):625-31.

9. Gomes A, Oliveira AV, Antunes JCP, Silva LR, Nascimento MAL, Silva MDB. The child victim of domestic violence: limits and challenges for nursing practice. Rev Pesqui Cuidados Fundamentais. [periódico na Internet]. 2010 [acesso 10 jul 2012]; 2(2):902-12. Disponível em http://www.seer.unirio.br/index.php/ cuidadofundamental/article/view/548

10. Cocco M, Silva EB, Hahn AC, Poll AS. Violência contra crianças e adolescentes: estratégias de cuidado adotadas por profissionais de saúde. Ciênc Cuidado Saúde. 2010;9(2):292-300.

11. Saliba O, Garbin CAS, Garbin AJI, Dossi AP. Responsabilidade do profissional de saúde sobre a notificação de casos de violência doméstica. Rev Saúde Pública. [periódico na Internet]. 2007 [acesso 16 jul 2012]; 41(3):472-7. Disponível em http://www. scielo.br/scielo.php?script $=$ sci_arttext\&pid $=$ S0034$89102007000300021 \& \mathrm{lng}=\mathrm{en} \& \mathrm{nrm}=$ iso

12. Zottis GAH, Algeri S, Portella VCC. Violência intrafamiliarcontraa criançaeasatribuiçõesdoprofissional de enfermagem. Fam Saúde Desenvol. [periódico na Internet]. 2006 [acesso 25 jul 2012];8(2):146-53. Disponível em http://ojs.c3sl.ufpr.br/ojs-2.2.4/index. php/refased/article/viewArticle/7989.

13. Deslandes SF, Gomes R. A pesquisa qualitativa em serviços de saúde: notas teóricas. In: Bosi MLM, Mercado FJ. Pesquisa qualitativa de serviços de saúde. Petrópolis: Vozes; 2004. p. 99-120.

14. Minayo MCS, Souza ER. É possível prevenir a violência? reflexões a partir do campo da saúde pública. Ciênc Saúde Coletiva. [periódico na Internet]. 1999 [acesso 10 jul 2012];4(1):7-23. Disponível em http://www.scielo.br/scielo.php?script=sci_ arttext\&pid=S1413-81231999000100002\&lng=en\&nrm =iso
15. Vargas JD, Silva KA. Diagnóstico de Uberaba, Teófilo Otoni e Itaobim: a rede de proteção. In: Cunha EP, Silva EM, Giovanetti MC. Enfrentamento à violência sexual infanto-juvenil: expansão do PAIR em Minas Gerais. Belo Horizonte: UFMG; 2008. p. 154-80.

16. Gomes R, Souza ER, Minayo MC, Silva CFR. Organização, processamento, análise e interpretação de dados: o desafio da triangulação. In: Minayo MCS, Assis SG, Souza ER. Avaliação por triangulação de métodos: abordagem de programas sociais. Rio de Janeiro: Fiocruz; 2005. p. 185-221.

17. Ferreira $A L, S c h r a m m ~ F R$. Implicações éticas da violência doméstica contra a criança para profissionais de saúde. Rev Saúde Pública. [periódico na Internet]; 2000 [acesso 9 jul 2012]; 34(6):7-23. Disponível em http://www.scielo.br/scielo.php?script=sci_ arttext\&pid=S0034-89102000000600016\&lng=en\&nrm $=$ iso.

18. Reichenheim ME, Hasselmann MH, Moraes, CL. Consequências da violência familiar na saúde da criança e do adolescente: contribuições para a elaboração de propostas de ação. Ciênc Saúde Coletiva. [periódico na Internet].1999 [acesso 16 jul 2012]; 4(1):109-21. Disponível em http://www. scielo.br/scielo.php?script $=$ sci_arttext\&pid $=$ S1413$81231999000100009 \&$ Ing $=$ en\&nrm $=$ iso

19. Nascimento AF, Garavelo MI, Kohls MEC, Cavalcante FG, Silva HO, Guimarães CF, Assis SG, Pereira LM. Conselhos Tutelares. In: Assis SG, Silveira LMB, Barcinski M, Santos BR. Teoria e prática dos conselhos tutelares e conselhos dos direitos da criança e do adolescente. Rio de Janeiro: Fiocruz; EAD/ENSP; 2009. p.139-224.

20. Vianna PCM, Vasconcelos M, Pinto VH, Donoso MTV, Ricas J. A saúde e as ações de enfrentamento à violência contra crianças e adolescentes. In: Cunha EP, Silva EM, Giovanetti MAC. Enfrentamento à violência sexual infanto-juvenil: expansão do PAIR em Minas Gerais. Belo Horizonte: UFMG; 2008. p. 235-58.

21. Nunes $C B$, Sarti $C A$, Ohara CVS. Profissionais de saúde e violência intrafamiliar contra a criança e adolescente. Acta Paul Enferm. [periódico na Internet]; 2009 [acesso 9 jul 2012];22 (n.esp.):903-8. Disponível em http://www.scielo.br/scielo.php?script=sci_ arttext\&pid=S0103-21002009000700012\&lng=en\&nrm =iso

22. Gonçalves HS, Ferreira AL. A notificação da violência intrafamiliar contra crianças e adolescentes por profissionais de saúde. Cad Saúde Pública [periódico 
na Internet]; 2002 [acesso 9 jul 2012];18(1):315-

9. Disponível em http://www.scielo.br/scielo. php? script $=$ sci_arttext $\&$ pid $=$ S0102-311X20020001000 32\&lng =en\&nrm=iso

23. Minayo MCS. O desafio do conhecimento: a pesquisa qualitativa em saúde. 7.ed. São Paulo: Hucitec; Rio de Janeiro: Abrasco; 2000. 269 p.

24. Minayo MCS. Conceitos, teorias e tipologias de violência: a violência faz mal à saúde individual e coletiva. In: Njaine K, Assis SG, Constantino P. Impactos da violência na saúde. 2.ed. Rio de Janeiro: Fiocruz; EAD-ENSP; 2009. p. 21-42.

25. Mioto RCT. A família como referência nas políticas públicas. In: Trad L. Família contemporânea e saúde: significados, práticas e políticas públicas. Rio de Janeiro:

Fiocruz; 2010. p. 51-66. 